\title{
THE OPERATION OF INNOVATION CLUSTERS IN LIGHT OF RELATIONSHIPS IN HUNGARY - QUALITATIVE RESEARCH FINDINGS
}

This paper discusses the operation of accredited innovation clusters in Hungary, applying qualitative methods. The focus of this research was to map the relations and cooperation within the clusters and their innovative effect. The aim of the study was to determine models and dimensions for revealing the intricate relationships by which we can describe them and by which they can be made measurable in the future. For this purpose, relationship marketing orientation, network competence, and proximity models that have already been presented in the international scientific literature were fitted to the cluster environment: the authors of this study interpret their dimensions in terms of the relations and cooperation within a cluster and examine their correlations with the cluster characteristics, as well as their impact on innovations.

Keywords: cooperation, innovation clusters, market orientation, network competence, relationship marketing orientation, relationship proximity

DOI: $10.15611 /$ aoe.2019.2.12

\section{INTRODUCTION}

One of the keys to the success of innovative companies is that they need to be members of networks which promote access to information and knowledge, and cooperation with stakeholders in the innovation chain (Bell et al. 2007; Zaheer et al. 2005; Koka et al. 2002).

Over the past two decades increased attention has been paid to clusters within networking organizations. In Western Europe and in the developed market economies cluster-oriented development has been preferred since the 1990s (OECD 1999). Here in Hungary, the concept of long-term cluster development has only been formulated since 2007 (Kovács et al. 2014; Horváth et al. 2013; MAG Zrt. 2012), hence only relatively fresh experience can be utilized. The most successful clusters have gained a foothold in the international arena as well, while others have stalled in their development, failed to obtain accreditation, or even closed. Revealing the reasons for the

\footnotetext{
* Department of Management and Corporate Economics, Budapest University of Technology and Economics, Budapest, Hungary.
} 
successes and failures, it has been concluded that the lessons are equally important tasks from the aspect of market participants and management. The positive impact of clusters on micro and macro level competitiveness have been addressed by several studies (Horváth et al. 2013; Europe INNOVA 2008; Porter 2008; Weisz 2008; Grosz 2005; Cooke 2001; Enright 1996), however, the question yet to be answered is what influence they exert and to what extent they encourage companies and scientific and research institutes to exploit the potential of cooperation opportunities of this organizational form.

The development of economic network cooperation evolving as a result of global competition has come to a new stage with the appearance of clusters. The introduction of the concept of clusters and the related theory can be linked to Porter (1990), in relation to the organization of local ventures, in connection with regional competitiveness. As a result of the intensification of clusterization processes, several types of clusters have appeared and simultaneously the interpretation of the concept has also diversified. We differentiate between regional clusters (the analysis of benefits that can be realized by regional clusters continues to receive great emphasis, particularly in international research (Bell et al. 2009; Todtling et al. 2005) and industrial clusters (the focus is on the value-added supply chains and defining them as corporations that are associated with the same value chain or as cooperation networks of associated institutions (Enright 1996; OECD 1999), and another classification distinguishes horizontal clusters, which make it possible for peer companies to achieve a common goal (Rosenfeld 2001) and are considered appropriate for combining institutions and enterprises operating in the service field of a certain region (Roncz 2007), and vertical clusters (mostly consisting of small and medium enterprises organized around a large corporation as a center, for example, supplier networks).

In theoretical research an important role is assigned to the exploration of the characteristics along which clusters can be considered to be specific economic networks. The most marked differences that can be seen are that while networks are rather exclusive, relatively stable organizations based on common business goals, they are also open, expansive in several directions, and offer more flexible forms of cooperation with a collective vision (Lengyel 2002). One important difference is that in clusters, cooperation is not restricted to business organizations. In clusters the institutionalized open flow of information and knowledge sharing can be detected (Sölvell 2009; Grosz 2005). 
Our research aims to contribute to the broadening of knowledge about practices related to accredited innovation clusters. Once these organizations reach a higher level, we assume that valuable experience has been accumulated regarding their operations. Our research targeted the exploration of relationship networks and cooperation in the context of relationship marketing orientation (RMO), network competence, and proximity in terms of their impact on innovation.

\section{THE RESEARCH TOPIC AND INTERPRETATION FRAMEWORK OF THE RESEARCH}

\subsection{The goal and method of the research}

In the course of our qualitative research we conducted personal interviews with the managers and member organizations of the domestic Accredited Innovation Clusters. Our goal was to explore what practical information and knowledge flow takes place, what kind of cooperation levels and forms are widespread, how they are affected by cluster characteristics (including the type of the cluster, the member composition, and the management board), how they all affect innovation, and how they promote the creation of successful novel products out of research and development $(\mathrm{R} \& \mathrm{D})$ ideas.

The target of our research was clusters and their affiliates, which had been awarded or had renewed their accreditation title as innovation clusters during the course of our research. The European Cluster Memorandum (2008) emphasizes the role clusters played in global competition from the aspects of efficiency and the effectiveness of the innovation activities and puts faith in the understanding that in modern competition, each cluster should become an innovation cluster. The period of data recording is from July 2012 to May 2015, during which time 21 innovation clusters were accredited. In the first stage of the research on which the presented results are based, we contacted 19 accredited innovation cluster management boards, which provided an access rate of 90.48 per cent. In the second phase of our research we conducted in-depth interviews with cluster members, and were able to contact 40 accredited innovation cluster member organizations including business enterprises, universities, and research institutes, as well. We applied NVivo qualitative data analysis software to evaluate the recorded in-depth interviews. Due to limitations of length, we only describe our most important observations as follows. 


\subsection{The operating characteristics of clusters and cluster management board}

When examining cluster characteristics we scrutinized the type of cluster and the composition of members. We also paid special attention to the mapping of sectoral specialties in the case of non-regional clusters. According to Barabási (2003), networks do not have a center, which means that if one element is removed from the net, it will not make the entire system inoperable. The same cannot be stated about clusters as the cluster management board itself is the junction that connects the members and provides a supportive background for cooperation. In our research, therefore, great emphasis was put on exploring the operational characteristics of the management. We analyzed the types and tasks of cluster management bodies (Dobronyi et al. 2012) as well as the operation forms of cluster management, financing solutions, maintaining contact with members, and also solutions facilitating cooperation among members. It was the interviews conducted with members and managers separately that provided the opportunity to examine the relationship between membership and management.

We wanted to show how the characteristics of cluster management organization and its operational practices affect membership, how they contribute to achieving innovation and market goals, as well as to reveal what expectations members formulate towards management and how satisfied or dissatisfied they are with its operation. It was taken as the basis that the harmonious relationship of members and management based on mutual trust is a preliminary condition of the organic evolution of clusters. (We came across several cases in which the management board was replaced because it could not cooperate with the members effectively, and there were also examples of cases in which an entity that had proven its abilities in other clusters took over management tasks).

\subsection{Cooperation between members}

When examining cooperation we started out with the assumption that the proper performance of the cluster management board could be measured by the level of cooperation between members. Effective management promotes mutual access to information as well as knowledge transfer and accumulation between facilities, through which a higher level of cooperation can be achieved. During our research we had to take into account the cluster feature that cooperation takes place at a broad platform on several levels, and depending on the aims of a project it varies in what range of members cooperate and to what extent they take part. So far we have only investigated cooperation between 
members, but we consider it important to extend research to their relations outside the cluster as well. In particular, cooperation between clusters-both domestically and internationally - deserves special attention, as it is one of the measures of the development of the clusterization process.

\subsection{Relationship marketing orientation (RMO)}

The pivotal foundation stone of network-type organizations is cooperation and relations between parties. Our research therefore considers it important to explore the factors which express the characteristics of a relationship that encourage or inhibit parties to mutually exchange their information, share knowledge with each other, exploit advantages available via relationships, and at the same time themselves create and offer opportunities for cooperation. In order to investigate all of these factors, the RMO model (Sin et al. 2005) was applied. The model incorporates six test dimensions: trust, bonding, empathy, communication, shared value, and reciprocity. Based on the model we investigated, following the abovementioned dimensions, to what extent RMO is present in the collaboration between members, how this is influenced by cluster characteristics, and with which solutions cluster management facilitates its realization.

Researchers have analyzed supplier and customer relationships with the help of this model, but in our opinion the analysis criteria are suitable for the mapping of cluster connections, and in the subsequent quantitative phase of the research relationship, features and bonds can be measured following the abovementioned dimensions. We consider this segment of the research worthwhile because it highlights bottlenecks and recommendations can be made for management regarding solutions that facilitate networking and collaboration.

\subsection{Network competencies}

Since clusters are network formations, it was also important to look at cooperation in the context of network competencies. As a theoretical foundation we assumed that the economic and business competencies of organizations can be defined as abilities that promote the generation and acquisition of benefits of competition originating from business opportunities. Hence, competence in this sense includes, on the one hand, a kind of organizational knowledge, and, on the other hand, the ability to exploit this knowledge (Czizmadia 2014). Gemünden et al. (1996) define the concept of networking competence, according to this approach, as the collection of resources and activities that can help organizations create, 
develop, and manage business networks. Network competence is considered a prerequisite for successful relationship management and network stability. With the help of this competence, strategic objectives can be realized through partner relationships which include not only their communication, but also mutual understanding and tolerance.

From another perspective, a high level of network competence ensures the dismantling of less effective relationships, while increasing the level of interaction between partners with high relationship potential. In our research we used Gemünden and Ritter's (2004) definition and interpreted it in the cluster environment. Thereafter, network competence can be seen as all the resources and activities with the help of which cluster management creates, develops, and manages the business relationship network of the members. Gemünden et al. (2004) place three relationship-specific components of the analysis of network competence into focus: initiation, exchange, and coordination. Our research has concentrated on these three elements so far. In the later stage of the research we expanded the dimensions of the investigation into network competence with elements based on Pihkala et al. (1999), such as communication skills, cooperative culture, trust, strategic thinking, visionary skills, and competence ensuring agreement to cooperation and implementing cooperation. In addition we aim to examine the existence of competencies not only from the aspect of cluster management, but also from that of the member companies. Furthermore, we also extended the network of connections to relationships outside of the cluster.

\subsection{Relationship proximity}

The initial interpretations of the concept of clusters focused on geographical proximity, as they were related to a regional nature. Subsequent studies (e.g. Porter 2000) have already highlighted that clusters might not only be considered as organizations of companies located geographically close together, but as innovative connection systems formulated for the sake of technological and knowledge exchange as well the basis on which tight relationship proximity is clearly determined. Proximity plays a decisive role in the transfer and diffusion of knowledge, hence it can be regarded as a relevant test criterion in the analysis of innovation cooperation. During the study of relationship proximity in our research, we applied the model of Boschma (2005), which defines relationship proximity along geographical, cognitive, organizational, institutional, social, and technological dimensions. 
These dimensions can individually and also synergistically promote the flow of knowledge and cooperation. In our research we looked for an answer as to how to interpret the above dimensions in a cluster environment, taking into account the different types of clusters and how they affect cooperation between members. It also needs to be mentioned for this criterion that the analysis can later be extended to non-cluster relationships. Examining proximity dimensions in inter-cluster collaboration can be an exciting topic with an additional survey of related industries. In our research we assumed that a relationship between the network competence of management organizations and the relationship proximity of the members exists. A higher level of network competence among the management board, including all three of the dimensions, leads to tighter proximity in the collaboration among members. We also assume that a higher level of RMO results in tighter proximity, and that the reverse relation is also true: a tighter relationship proximity represents more favorable grounds for the implementation of the analyzed marketing dimensions.

\subsection{Innovation}

In the concept of network collaboration, knowledge and learning appear as key factors for speeding up the innovation process (Bertola et al. 2003). It was also the primary assumption of our research that clusters provide environmental and organizational conditions that are favorable in terms of the efficiency and effectiveness of innovation activity. Successful innovations can be realized through the exploitation of opportunities inherent to collaboration, which can be linked to RMO, network competencies, and relationship proximity. We investigated the innovative role of clusters in terms of their contribution to the market orientation of innovations. They could provide a proper framework for cooperative partners to be able to integrate their competencies and resources, whether that is from a technical aspect or also in terms of helping each other in the successful market utilization of innovative solutions.

\section{PRESENTATION OF RESULTS AND DISCUSSION}

Figure 1 displays the influences exerted on cooperation by the factors, which we analyzed that can be observed in clusters, as well as on the implemented innovations. Hereinafter, the results we arrived at are presented for each factor. 


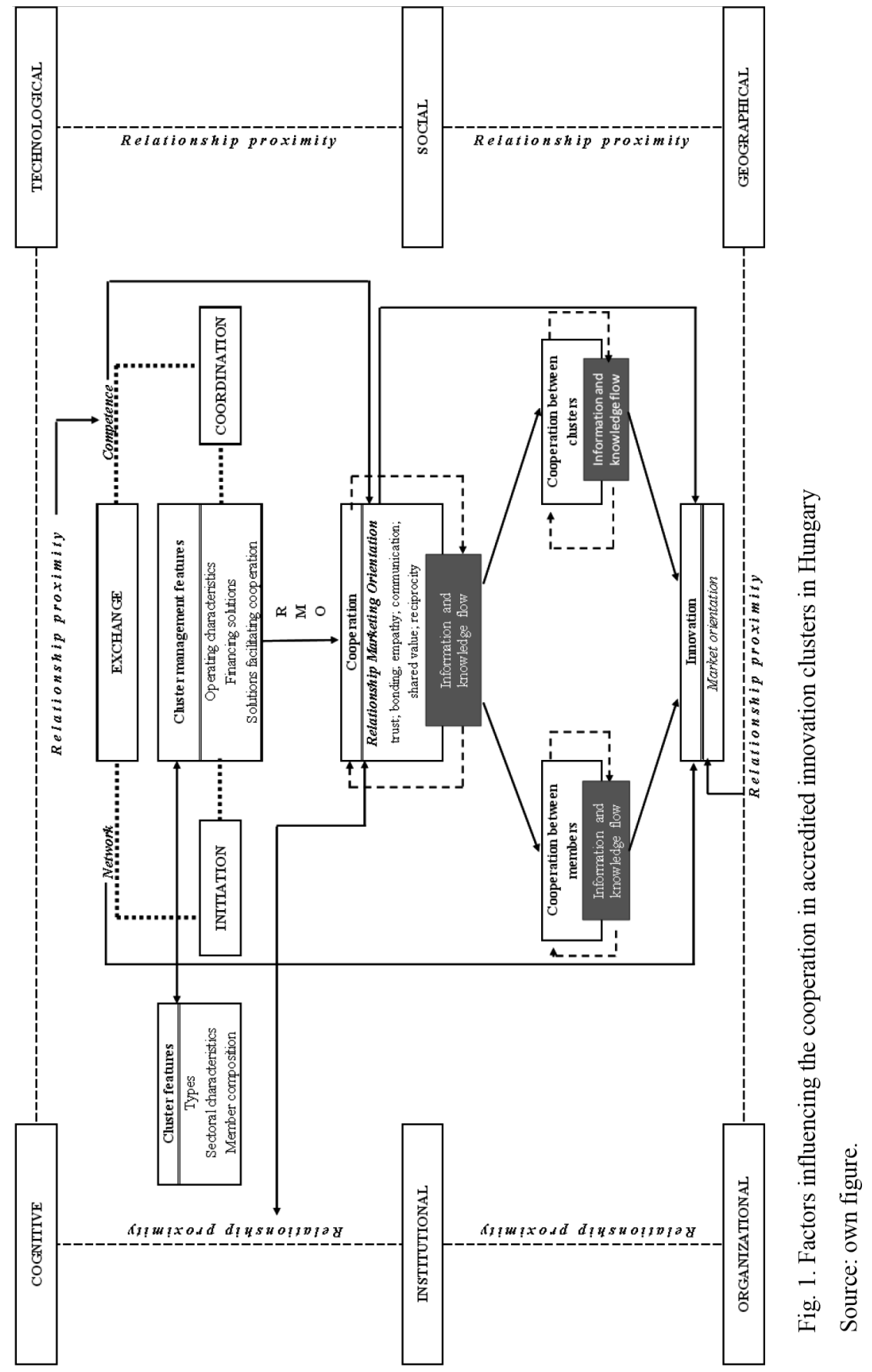




\subsection{Cluster features and management board}

The clusters that were sampled show a variety of types and member compositions. Regional and sectoral considerations are both present in the domestic clusterization process, and indicated that the effect of geographical proximity and that of sectoral specifics could be investigated. In the case of certain clusters these are closely linked, for example the Pharmapolis Debrecen Innovative Pharmaceutical cluster, which incorporates the parties of the region in order to promote industry networking. A significant difference was found between clusters, mainly in connection with sectoral characteristics, in the aspect of whether competitors can appear among members. In a mainly market-based cluster, the most important goal is to improve the market position of its members. As a consequence, competitors are not allowed to join. The expected benefits are mainly marketing related: the greater insight into the market, the better understanding of the opportunities regarding both potential customers and suppliers, sharing information and experience, and facilitating building relationships (for instance the plastic packaging industry). They focus on complementary competencies in order to be able to cover wider and wider market segments in the sector. The studied clusters also differed in the aspect of whether they allow the admittance of foreign-owned companies. For example, in medical clusters the most important advantage that producers expect is gaining new markets through joint action, which are partly export market goals and partly seeking a domestic market niche. Since the aim is to pool domestic companies, foreign-owned companies cannot be among the members. On the contrary, IT clusters are characterized by the presence of competitors.

Regarding the size of member companies, variations can be observed, which also correlates with sectoral characteristics. Clusters that are inhomogeneous in terms of the size of their members and even in the ownership structure tend to realize benefits originating from the collaboration of small and large companies. It is characteristic of the IT sector that among members there are also a relatively large number of startup companies. For them, access to resources, a well-developed information system, and the incubating role of cluster management are especially important.

During interviews conducted with vertically structured clusters it appeared to be an advantage that members could create an internal market, since they are users of each other's products, and in the relation of external customers they are able to complement each other's bids. Internal commerce 
also makes it possible to replace their previous suppliers with each other. If customers order from several cluster members, it is an advantage from a logistics point of view as well.

In strongly knowledge-driven vertical clusters, the inhomogeneous nature and extensive scope of partnerships - groups of companies, academic institutions, local governments - are especially beneficial for information and knowledge flow, enhance relationship building, and allow very strong synergies to be utilized, for example in the fields of environmental protection and the energy sector where these statements are confirmed by Bíró-Szigeti and Vágási (2016). In the quality of life, food, and pharmaceutical sectors, vertical chain cluster-based organizations were also established in which complementing each other's activities and portfolio was emphasized.

During our research we found that sectoral characteristics are expressly present in the vision of clusters, membership criteria, collaborative solutions, and the forms of solutions that are to be applied. The innovative goals and market characteristics of the cluster members also show a strong correlation with sectoral characteristics, and, as we saw in the previous examples, it can be inferred from this which goals motivate entry and which innovative and market advantages are expected from the membership. In addition to determining clusters with sectoral specialties, there are clusters characterized by a cross-sectoral nature, such as the connection of the plastics industry and the packaging and printing industry.

As competitors may be represented in clusters, it is common practice that tasks related to collaboration and operational management are not carried out by one of the member companies or organizational units but by a distinct cluster management board. In their scope of responsibility tasks that are quasi-permanent mingle with tasks related to on-going projects. Several studies have pointed out (e.g. Buhl et al. 2009) and our research has confirmed as well that the expertise and performance of cluster management is a key factor regarding a cluster as a whole. In the case of clusters, the management board plays the role of a catalyst to enhance the cooperation of the members, to coordinate their intentions and opportunities of cooperation. At the same time, it can fulfill a bridging role between the professional side and the external parties, especially venture capitalists.

As the composition and the number of members can continuously vary, the management body plays a mediating role in building relationships between the old and the new members. The fact of whether a cluster is able to finance its own management organization, greatly depends on how strong 
the involved companies are financially. This, however, can differ significantly as a function of market conditions (Kovács et al. 2014). In our research we examined which solutions different management organizations used to help the cooperation of the members. These include a variety of management services (marketing and PR activities, promoting joint representation at exhibitions and fairs, joint actions to promote press releases, cluster brand formulation, strengthening relations, lobbying, training, education), ensuring financial resources (tender funds, resources dedicated to clusters, JEREMIE investment funds, venture investors), members providing access to information, and applying formal and informal networking mechanisms (working groups, benchmarking meetings, workshops).

\subsection{Cooperation between members}

The purpose of the creation of clusters is to generate cooperation based on mutual interests. Cooperation can be established among cluster members in relation to clusters and external parties (such as managing, representative, and regional institutions) and also clear ambitions can be observed to establish inter-cluster cooperation. It is common practice that clusters establish so-called co-cluster relationships between themselves e.g., association of accredited clusters of innovation in the ICT sector, enter into cooperative agreements, and organize joint events. Cooperation between clusters can be formed across sectors and also within a given industry.

As we have previously indicated, at this stage of our research we have confined ourselves to examining cooperation between members. Clusters provide a broad platform for cooperation between their members by the fact that not only economic enterprises may become members, but also universities, research institutes, and other institutions promoting the expansion of university research activities and the economic utilization of their intellectual property. During our research we aimed to map multiple sections of the anticipated benefits of cooperation and the forms of cooperation. In clusters of only micro-, small-, and medium-sized companies the aim of cooperation is increasing bargaining power and having a joint presence in the market; they wish to realize these benefits by joining forces. But the corporation among the direct competitors of micro and small companies is barely observed in the energy sector (Bíró-Szigeti 2014), because the enterprises are continuously making price comparisons and also they have different missions and objectives for their operation fields. However, their main business objective is the same. 
In the case of inhomogeneous clusters, innovative ideas are typically suggested by micro and small enterprises, and the market introduction of the idea is ensured if large enterprises can build them into their portfolios. Through membership, relations clusters can convey information on what know-how they need, which gives direction to $R \& D$ trends, in turn promoting their market utilization. Moreover, it can even make technical education more oriented. It is a general characteristic of clusters that they are open to universities and that they even tend to encourage their membership by making it free of charge.

\subsection{Relationship marketing orientation (RMO)}

In this section we turn to the elements of RMO. As previously implied, so far the investigation has only covered relationships between members. Based on our experience, we briefly summarize what role they play in the cooperation of the members, how cluster features affect the individual components, and what solutions the management can apply in order to improve their level.

Trust determines the level at which the related parties feel that they can trust their partners and they will keep their promises for the future (Szabó et al. 2013). The higher the level of trust, the more likely a long-term relationship between the parties (Sin et al. 2005). Trust is a critical factor in the successful operation of clusters. The operation of clusters is dominated by the domestic entrepreneurial attitude that sharing information and knowledge is still quite an alien concept. As one interviewee put it: "In order to achieve their own business goals a 'guerilla war' is often going on." The extent of how hard or easy it is to create an atmosphere of trust is greatly influenced by the nature of the cluster and the admission criteria. In inhomogeneous clusters, and if competitors can be present among members, it is more difficult to overcome the constraints of distrust, placing a large burden on the management.

At the same time we saw several positive examples of the phenomenon that with good management practices, interests can be focused in the same direction and competitors look for joint solutions to solve their common problems, exchanging their experiences in the process. Building trust relationships with universities is complicated by the still detectable "ivory tower" behavior. The atmosphere of trust is also affected by the extent to which the creation of clusters relies on grassroots initiatives. From the aspect of trust it is more favorable if the foundation relies on existing partnerships 
or network connections for which we could find several examples. In the case of a successful operation through the development of clusters, members become closer to one another and mutual trust is strengthened via the implementation of joint projects.

Bonding determines how strong the commitment of the parties involved is to the relationship, and therefore to cooperating and to realizing their common goals. The stronger the bond, the more likely it is that they seek to maintain a long-term relationship (Sin et al. 2005). In the case of clusters, bonding is manifested in how the management can harmonize the companies by way of finding tenders, catalyzing joint projects, and realizing the results of knowledge sharing in joint cluster products. "Cluster coordination and the president of a cluster have enormously significant roles. It is easier to overcome problems if an acknowledged person leads the cluster. Otherwise, only fake relations and fake bonding can formulate". The more successful a cluster is in this regard, the more successful tenders it wins, and the stronger the bonding of the members to each other but also to the management will be, which increases their commitment to the relationship, too. Trust and bonding thus reinforce each other through the implementation of joint projects in the event of a successful cluster operation.

In clusters, as opposed to other business networks, so-called free-riders may appear, which runs against both trust and bonding. Therefore, it is important that the management should filter out inactive members and remedy this problem. In order to do so it needs to make them interested in meaningful collaboration; if necessary, it must find solutions needed for their realignment (we found an example in which the lack of language skills hindered participation in the tender of work). We first encountered the freerider problem in the field of IT clusters, which is possibly related to the fact that this cluster has the most significant developmental differences.

Good communication is an essential condition for the development of trust and cooperation in relationship marketing. The better the communication skills each partner has, the higher the value of RMO (Sin et al. 2005). Information flow and communication is manifold and multilayered within the cluster as well as outside it. This feature of cluster communication originates on the one hand from the fact that membership consists of different types of organizations and institutions. On the other hand, during collaboration on joint projects or outside of them the "cast" itself represents diverse professional knowledge, competence, and job positions (small entrepreneurs, corporate leaders, academics, researchers, developers, marketing specialists, coordinators, consultants, etc.). Due to 
different competencies and professional cultures it is not easy even to develop a common language in a certain project. Management plays an important role at this point, as its bridging role allows it to create a context in which the emergence of a common language can take place (workshops, organizing formal and informal meetings, etc.). Internally the main objective of communication is to facilitate cooperation and to support the required exchange of information.

Further important aims are generating projects and ideas, as well as the recruitment of new members, since in many cases acceptance of new members begins with internal recommendation. In the case of external parties, formulating and strengthening the image and reputation of the cluster as well as lobby activities in governmental relations have an important role in communication. In our research we also mapped the tools of external and internal communication, but their presentation is beyond the scope of this study.

The shared values determine what the participants of the relationship consider right or wrong behavior in business life. Common goals and values result in a stronger relationship commitment (Sin et al, 2005). The shared values are reflected in the cluster's vision and mission. They are strongly penetrated by sectoral specifics which are also related to market and innovation objectives. Recovering lost domestic market positions in the medical device industry, in the development of real biodegradable packaging materials, achieving a market leader position in the plastic packaging industry, and facilitating the market appearance of the innovative achievements of inventors, university researchers, and start-up entrepreneurs in the IT field can be mentioned as examples. In the case of innovation clusters, shared values are also formulated as common goals for the benefit of the community, such as the sectoral innovation chain for strengthening less developed elements along with export interests (such as pharmaceuticals), new skills (such as eco-competence), establishing development trends, creation of knowledge centers, boosting innovative sectors, development of a certain region, increasing employment, and even asserting responsible corporate behavior (e.g. clusters operating in the field of environmental industry). The more members can identify themselves with the mission of the cluster, the stronger the bond that can develop between them.

Empathy also allows partners to understand and see the goals and aspirations of each other from their point of view. Empathy is essential for establishing long-term positive relationships ( $\operatorname{Sin}$ et al, 2005). We also 
associated the extent to which members can feel empathy towards each other with member composition. In homogeneous clusters in which only SMEs are the members, parties are able to identify themselves with each other's goals, especially when they are still strongly linked to a common sectoral vision. Where foreign-owned corporations are also included in the membership, it is more difficult to accept each other's perspectives and one can find more examples of relationship failures and hurt feelings (such as unsuccessful performances in a prototype competition). The presence of competitors is interesting in this respect, because it is harder to develop an atmosphere of trust but at the same time, as they have common problems, they can feel empathy toward each other each other more easily, which - if the management performs well - can lead to common solutions.

Reciprocity in relationships means that each party does greater or lesser favors and make allowances for each other in order that they can receive similar "benefits" in the future (Sin et al. 2005). During our research we found that vertical value-chain based organizations provide better grounds for reciprocity. To do so, they can utilize the relationship network of each other and their experience in different fields. "We support their marketing work, and they help us in the development of our products. We do not get into each other's way".

\subsection{Network competence}

Based on the above-described findings in our research up to this point, we interpret network competence in relation to cluster management, including its resources and activities, in terms of how it manages the relationship network of its members. We assume that the successful operation of a cluster depends on how competent the cluster management is in creating a collaborative and cooperative environment. Thus we note that competence can be interpreted on two levels: on the level of individual projects, or referring to the relationship network of the entire cluster. From now on we will discuss the three components indicated at the interpretation framework.

At the element of initiation, we examined how management promotes the tracing and identification of potential partners. The organization of cooperation is typically performed by the management board whose activity includes the recommendation of members for a potential tender or project. To accomplish this, continuously updated knowledge of tender opportunities is needed, as well as the objectives, possibilities, and limits of each party and of the innovative directions feasible within the framework of collaborations. 
Exploring contact synergies and their utilization is important. Of course, recommendations by members also play an important role, and these are typically implemented via workshops and public meetings organized by the cluster management. The opinion of the membership about the proactive role of the management varied even within a single cluster. In general, we found that members were satisfied with the proactivity of the management, but we found examples of cases when they expected a more active initiative role: "We are burdened with our own problems. It would be good if they pushed us to deal with a tender, it is for us!". Within one single cluster more active companies had the opinion that the slow reaction of certain cumbersome members blocks the implementation of management-initiated collaborations.

We analyzed the exchange component to find out what practices clusters follow to exchange market and technical information, knowledge, and technology. Information transfer between members can take place by way of databases, trend monitoring, and information communication equipment (CRMs, benchmarking information). Members may be active participants of social events, discuss issues related to a given topic (developments, projects, tenders, etc.), or be able to listen to lectures. In several clusters, management operates working groups to discuss these various development topics and ideas e.g. on operations, strategy, tenders, etc.. Benchmarking meetings may be organized around a variety of topics, providing an opportunity to exchange knowledge on and experience in the best practices of certain functional areas such as marketing communications. Evoking awareness of running projects is also a good opportunity to explore potentials for cooperation. Significant differences can be observed in how much cluster management organizations favor and promote during informal meetings; regarding the assessment of their usefulness, there are also significant differences among the members. Most examples of informal initiatives being supported can be found in the IT sector.

With regard to coordination, it can be stated that it is the responsibility of the management organization to coordinate joint activities, development processes, to define formal regulatory approaches, and to manage occasional conflicts. Coordination tasks include both internal and external relations of a cluster. As clusters are open and flexible formations, their internal environment is constantly changing, which is a continuous organizational challenge for the management. In our research we examined various coordination mechanisms that promote the integration of knowledge and the harmonization of interests through effective processes of integration and tools of communication. We examined the tasks related to the activities of 
the input and output side separately. The former covers, for example, the provision of the financial resources necessary for the operation, while the latter can include the creation of opportunities for joint action in the market and the coordination of participation at exhibitions and fairs.

\subsection{Relationship proximity}

Now we examine how the proximity dimensions presented among the theoretical principles affect the relationships between the members.

Cognitive proximity. Companies in cognitive proximity are able to acquire new knowledge, experience, and information and to share them thanks to their similar knowledge base and common professional language (Boschma 2005). According to Nooteboom (2000), this kind of proximity facilitates effective communication, since parties (organizations and individuals) in the same cognitive level can share knowledge and skills more effectively, even if they have different corporate cultures, customs, and norms. Because of the wide network platforms, the membership of clusters consists of individuals and organizations which possess a variety of knowledge, competencies, technical and market insight, preparedness, innovation skills, and capabilities. The "cluster product" of an innovation project is created as a result of common knowledge. The advantage of clusters can be defined as the very capability to bring different professional competencies closer through joint projects, to provide a broad view on the entire innovative value chain, it combines the fields of science, technical development, manufacturing, and marketing. Therefore, while networks are mainly characterized by codified (explicit) knowledge, clusters furnish a wide space to the utilization of hidden (tacit) knowledge (Cooke 2001). Members can learn from one another, while they can also exert a pulling force on each other. They are propelled toward continuous renewal through the development of relationships, and they can acquire thinking in long-term cooperation. It has already been mentioned that the successful management of clusters requires manifold preparedness and special skills. The role of cognitive proximity in collaboration, especially in the case of knowledge based clusters, is important.

Organizational proximity. It refers to the presence of relationships in the same space (Boschma 2005). Organizational proximity hastens collaboration and knowledge sharing, as at the same time it is the coordinative tool of complementary information flowing between members and of knowledge exchange, thus affecting learning, innovation, and knowledge processes, 
mutual understanding, and trust building (Hau-Horváth et al. 2014). Presence in the space is provided by the cluster itself as an open, democratically operating organization relying on significantly nonformalized relationships. The growing popularity of clusters suggests that this type of organizational proximity enjoys trust and is suitable for the promotion of the processes described above. The pulling force of organizational proximity (belonging to one cluster) could well be explored with the help of the question: "What would you have lost if you had not entered the cluster?". Most interviewees highlighted personal relationships, partnerships, tenders, and the innovative environment. The answers properly outlined the level of activity of the members as well as the level of development of clusters.

Social proximity. It alludes to the embedding of the relationship of individuals and organizations in a social system which is based on confidential personal bonds. Economic relations are always embedded in a social context, and the greater the rate of embedding within a company, the better innovation performance can be achieved. Social proximity allows for effective interactive learning and the formation of dedicated long-term relationships (Boschma 2005). As previously mentioned, clusters provide a favorable organizational framework for the usage of tacit knowledge. We highlight it here again as social proximity and relations of trust are extremely important in terms of tacit knowledge, because by their nature they would be more difficult to convey and publish through market mechanisms. This brings us back to the idea that the key to the successful operation of clusters lies in relationships that are based on trust.

Institutional proximity. It defines the same or similar relationships that are formulated in the formal and informal institutional environments shared and accepted by organizations (Boschma 2005). The notion of social proximity is analyzed on the basis of the strength of the relationships implemented at a micro level, whereas institutional proximity is defined within a macro-level institutional framework. In the case of the studied clusters, institutional proximity was interpreted based on accreditation and its institutional and regulatory background. In Hungary, management functions are performed by MAG Zrt., the Hungarian Economic Development Center. Although there were opinions according to which accreditation is only an administrative process the benefits of which cannot be detected, clusters involved in our research typically assessed the role of accreditation positively, especially with respect to project proposals, tenders, and the development of foreign relations. The positive effect of accreditation 
was also noted in building relationships with multinational companies or in members being invited to clusters with which they could not otherwise form collaboration. Members of research institutes and universities also composed reviews in which they stated that they were recruited by clusters because there was a need for the accreditation clusters to have a research and development background. Some of the interviewees complained that few tenders are announced specifically for accredited clusters.

Technological proximity. It means the closeness of economic players based on their technological experience and knowledge base (Knoben et al. 2006). Innovation clusters are designed to provide a favorable organizational framework for the creation, dissemination, and flow of technological knowledge. In the case of members which are represented in similar technological areas, solving common problems is emphasized, while in the case of complementary competencies it is combining elements of technological know-how which the clusters can promote. For universities and research institutes, cluster connections help to convert technological knowledge into the environment of enterprises and find partners for practical utilization. The established practice of the dissemination and flow of technological knowledge is a prototype competition.

Geographical proximity. It is the basis of regional cluster organizations and so far it has been the exploration of benefits related to this that has received the greatest attention in recent research. This is not a coincidence as the majority of the accredited innovation clusters are related to regional centers.

Certain dimensions of proximity also exert an impact on network competencies and skills. Beyond examining the relationship between each member, they determine the endeavors of the cluster management supporting coordination and cooperation that greatly affect the network competencies of the cluster management.

\subsection{Innovation}

Collaborating partners are not only able to integrate their competencies and resources from a technical point of view, but they can also help each other in successfully utilizing innovative solutions in the market (Kovács et al. 2012). Through cluster relations and the supportive mediation of the management organization, it is easier to achieve access to market information, a broader view of the market, and a better understanding of the competition. The conversion of R\&D achievements into market successes 
can be promoted by joint market action, the acquisition of new markets using each other's contact networks, or even the creation of an "internal" market by purchasing from each other. The market introduction of the products and services created by members may be accelerated via the promotional or communications platform of the cluster or through its connection network. All of these trends promote the interconnection of consumer value and technological development and the market-orientation of innovations - for example in energy sector connected to Bíró-Szigeti's work (2014).

\section{CONCLUSIONS}

The results presented in this study are based on qualitative research, yet they shine a light on what factors affect the formation of cooperation in domestic accredited innovation clusters and how these factors directly or indirectly influence the degree of market orientation of innovation.

It can be said that the clusters are determined by their own characteristics (composition, sectoral characteristics, etc.) and that they have an impact on the level of cluster management coordination and networking competencies. During our research we found that sectoral characteristics are strongly expressed in the vision and membership criteria of clusters and in the applied cooperative solutions and forms. We believe that with the measurement of network competence it is possible to answer which knowledge and managerial competencies are needed by the organizations to manage and coordinate more effectively the cooperation between member companies. While conducting in-depth interviews, our assumption was confirmed that the successful operation of clusters depends on how competent cluster management is at creating a collaborative and cooperative environment.

Our qualitative research also revealed that the RMO scale can be used to map the relationship orientation of the domestic accredited innovation clusters, as well as that out of the six factors described in the study, the most critical success factors are trust, bonding and communication. We demonstrated that if a strong RMO can be observed within the cluster, it also affects the cooperation implemented by the member companies, and indirectly influences innovation. Our in-depth interviews also showed that clusters may not only be considered as organizations of companies that are located geographically close to one another, but also as close innovative connection networks created for technological and knowledge exchange which are clearly based on relationship proximity. While investigating this 
factor we also need to consider relationship, organizational, institutional, technological, social, and cognitive proximity.

Obviously, additional quantitative research is needed to support the results presented in this study with numerical data. Our future plans include the investigation of correlations that we explored during our qualitative research focusing on a specific industry, as well as adapting the presented measurement methods (levels of proximity, networking competence, RMO) and measuring the impact of each factor on the market orientation of innovations.

\section{REFERENCES}

Barabási, A-L., Behálózva, A., Hálózatok új tudománya [The role of networks in the authorization]. Magyar Könyvklub, Budapest 2003.

Bell, G. G., Zaheer, A., Geography, networks, and knowledge flow, „Organization Science”, pp. 955-972, 2007.

Bell, S., Tracey, P., Heide J. B., The Organization of Regional Clusters, „The Academy of Management Review", 34, 4, pp. 623-642, 2009.

Bíró-Szigeti, Sz., Strategy support of residential energy saving investments in Hungary with the method of technology roadmapping, „Acta Polytechnica Hungarica”, 11, 2, pp. 167-186, 2014.

Bíró-Szigeti, Sz., Vágási, M., Stakeholder relationship of household investments into residential building energy saving projects - modelling approach of the Hungarian case, „Argumenta Oeconomica”, 2(37), pp. 147-168, 2016.

Boschma, R. A., Proximity and innovation: A critical assessment, „Regional Studies”, 39, pp. 61-74, 2005.

Buhl, C. M., Köcker, G. M., Cluster Management Excellence. Volume1: Network services. http://www.kompetenznetze.de/service/bestellservice/medien/en_clustermanagementi_onl ine.pdf1, 2009.

Bertola, P., Teixeira, J. C., Design as a knowledge agent: how design as a knowledge process is embedded into organizations to foster innovation, „Design Studies”, Vol. 24, Issue 2, pp. 181-194, 2003.

Cooke, P., Clusters as key determinants of economic growth [in:] Mariussen, Å. (ed.), Cluster policies - cluster development?, pp. 23-38. Nordregio Report, Stockholm, 2001. http://www.nordregio.se/Global/Publications/Publications\%202001/R2001_2/R0102_p23. pdf

Csizmadia, Z., Az innováció hálózati alapú megközelitése [The network-based approach of innovation], [in:] Hardi, T, Nárai, M. (eds.), Térszerkezet és területi folyamatok: Tanulmánykötet Rechnitzer János tiszteletére, pp. 125-146. Pécs; Győr: MTA KRTK Regionális Kutatások Intézete, 2014.

Dobronyi, T., Halmos, L., Somosi, É., Klasztermenedzsment: Magyarország [Clustermanagement: Hungary]. Complex Kiadó, Budapest 2012. 
Enright, M. J., Regional clusters and economic development: a research agenda [in:] Staber, U. et al. (eds.), Business Networks: prospect for regional development. Walter de Gruyter, Berlin 1996.

Europe INNOVA, The concept of clusters and cluster policies and their role for competitiveness and innovation: main statistical results and lessons learned. Commission Staff Working Document. Luxembourg 2008.

Gemünden, H. G., Ritter, T., Heydebreck, P., Network configuration and innovation success: an empirical analysis in German high-tech industries, „International Journal of Research in Marketing" 13, pp. 449-462, 1996.

Gemünden, H. G., Ritter, T., The impact of a company's business strategy on its technological competence, network competence and innovation success, „Journal of Business Research”, 57, pp. 548-556, 2004.

Grosz, A., Klaszteresedés és klaszterorientált politika Magyarországon [Development of clusters and cluster-oriented policy in Hungary], Doctoral thesis. Pécs 2005.

Hau-Horváth, O., Horváth, M., A földrajzi közelség szerepe az innovációs együttmüködésekben - illúzió vagy valós tényezö? [The role of geographical proximity in the innovation collaboration - an illusion or real factor?], „Közgazdasági Szemle”, LXI, pp. 1419-1446, 2014.

Horvát, M., Kerekes, I., Patik, R., Elemzés a magyar klaszterfejlesztés elmúlt 4 évéröl (tények és tanulságok) [Analysis of the Hungarian cluster development in the past 4 years (facts and lessons learned)], 2013, http://klaszterfejlesztes.hu/content/cont_51d4102c8c68e4. 02287351/elemzes_a_magyar_klaszterfejlesztes_elmult_4_everol.pdf].

Kovács, I., Petruska, I., A piacorientáció érvényesülése az innovációs klaszterek müködésében [The enforcement of the market orientation in the functioning of innovation clusters] [in:] Topár, J. (ed.), A müszaki menedzsment aktuális kérdései, pp. 343-360. Müszaki Kiadó, Budapest 2012.

Kovács, I., Petruska, I., Operational characteristics of Hungarian innovation clusters as reflected by a qualitative research study, „Periodica Polytechnica, Social and Management Sciences", Vol. 22, No. 2, pp. 129-139, 2014.

Koka, B. R., Prescott, J. E., Strategic alliances as social capital: A multidimensional view, „Strategic Management Journal”, 23, pp. 795-816, 2002.

Knoben, J., Oerlemans, L. A., Proximity and inter-organizational collaboration: A literature review, „International Journal of Management Reviews”, Vol. 8, No. 2, pp. 71-89, 2006.

Lengyel, I., A klaszterek fejlesztésének általános tapasztalatai; A hazai épitöipari versenyképességének javitása: a klaszterek szerepe a gazdaságfejlesztésben [General findings of cluster development. Improving the competitiveness of the domestic construction industry: The role of clusters in economic development], Lengyel, I., Rechnitzer, J. (eds.), Régió Art, Györ, pp. 99-124, 2002.

Mag Zrt., A magyar klaszteresedés elmúlt 3 éve az akkreditált innovációs klaszterek példáján keresztül [Cluster development in the past three years in Hungary with an example of the accredited innovation clusters], 2012, http://magzrt.hu/nyomtatvanyok//Klaszterek_ elemzese_2012.pdf.

Nooteboom, B., Learning and innovation in organizations and economies. Oxford University Press, Oxford 2000. 
OECD, Boosting innovation: The cluster approach. OECD Publishing, 1999, http://dx. doi.org/10.1787/9789264174399-en.

Pihkala, T., Varamaki, E., Vesalainen, J., Virtual organization and the SMEs: a review and model development, Entrepreneurship and Regional Development, 1999.

Porter, M. E., The competitive advantage of nations. Free Press, New York 1990.

Porter, M. E., Location, clusters, and company strategy [in:] Clark, G. L. et al. (eds.), The Oxford Handbook of Economic Geography, pp. 253-274. Oxford University Press, Oxford 2000.

Porter, M. E., Clusters and competition: New agendas for companies, governments, and institutions, pp. 213-304. Harvard Business Press, Boston 2008.

Rosenfeld, S. A., Community college/cluster connections: Specialization and competitiveness in the United States and Europe, „Economic Development Quarterly”, Vol. 14, Issue 1, pp. 51-62, 2001.

Roncz, J., A klaszteresedés tendenciái [The tendencies of cluster development], „Polgári Szemle" 3, 7-8, 2007.

Sölvell, Ö., Clusters - balancing evolutionary and constructive forces, second edition. Ivory Tower Publishers, Sweden, 2009.

Sin, L. Y. M., Tse, A. C. B., Yau, O. H. M., Chow, R. P. M., Lee, J. S. Y., Lau, L. B. Y., Relationship marketing orientation: Scale development and cross-cultural validation, „Journal of Business Research”, 58(2), pp. 185-194, 2005.

Szabó, S., Ferencz, V., Pucihar A., Trust, innovation and prosperity, „Quality Innovation Prosperity/Kvalita Inovácia Prosperita", Vol. 17, No. 2, pp. 1-8, 2013.

Todtling, F., Trippl, M., One size fits all? Towards a differentiated regional innovation policy approach, „Research Policy” 34, pp. 1203-1219, 2005.

Zaheer, A., Bell, G. G., Benefiting from network position: firm capabilities, structural holes, and performance, „Strategic Management Journal”, 26, pp. 809-825, 2005.

Weisz, Á., A klaszteresedés, mint gazdaságfejlesztő erö, a pannon termál klaszter Zala megye gazdasági fejlödésére gyakorolt hatásain bemutatva [Cluster development as a force of economic development, the effects of the Pannon Thermal Cluster on economic development in Zala county], 2008, http://elib.kkf.hu/okt_pub1/szf_22_11.pdf.

Received: October 2017 